\title{
DCX wt Allele
}

National Cancer Institute

\section{Source}

National Cancer Institute. DCX wt Allele. NCI Thesaurus. Code C75323.

Human DCX wild-type allele is located within Xq22.3-q23 and is approximately $119 \mathrm{~kb}$ in length. This allele, which encodes neuronal migration protein doublecortin, plays a role in the mediation of neural migration. Mutations in the gene are associated with lissencephaly X-linked type 1 and subcortical band heterotopia X-linked. 